\title{
Clinical efficacy of ayurveda treatment modalities in the management of garbhashosh (intrauterine growth restriction): a systematic review
}

\author{
Sarika T. Shinde* \\ Department of Kaumarbhritya, Gaud Brahmin Ayurvedic College and Hospital, Brahmanwas, Haryana, India
}

Received: 18 September 2020

Revised: 21 October 2020

Accepted: 26 October 2020

\section{*Correspondence:}

Dr. Sarika T. Shinde,

E-mail: drsarika843@gmail.com

Copyright: ( $\odot$ the author(s), publisher and licensee Medip Academy. This is an open-access article distributed under the terms of the Creative Commons Attribution Non-Commercial License, which permits unrestricted non-commercial use, distribution, and reproduction in any medium, provided the original work is properly cited.

\begin{abstract}
Concept of fetal well-being has gained importance in conventional science in recent era, but this concept of 'supraja janana' was a prime concern of Ayurveda since old era. Apart from prematurity, intrauterine growth restriction (IUGR) is a major public health problem in most of the developing countries. While going through ayurved classics it is revealed that garbhashosh is one of the disease, which is comparable to intrauterine growth restriction in modern medicine. In Ayurveda various drugs and preparations have been described for treatment of garbhashosh. These drugs are comparatively safe without any unwanted side effects. Aim of this work was to review and meta-analyze the effictiveness of various ayurvedic treatment modalities for garbhashosh with respect to (w.r.t.) IUGR. An attempt to expand the concept of IUGR according to Ayurveda and to yield a flourishing result to this world-wide problem through Ayurveda, this topic has been selected for the study. Going through pathology and main clinical signs and symptoms, garbhashosh can be correlated with IUGR. It is observed that, total 5 clinical studies and 1 case study have been reported on management of IUGR by using classical formulations of Ayurveda. The results and observations obtained through demographical data, effect of therapy observed on the ultrasound parameters as well clinical parameters of garbhashosh w.r.t. IUGR were statistically significant. Results were obtained in favour of most of the ayurvedic formulations. Through this review it can be stated that bruhaniya gana sidha kshirbasti and kshirpan, shatavari kshirbasti, shatavaryadi kshirbasti, yashtimadhu vidari siddha kshirbasti, shatavari ashwagandha phalaghruta kshirbasti, can be given to a pregnant women with IUGR after completion of $28^{\text {th }}$ weeks of gestation, without any complication either in mother or in child. It is cost effective as compared to modern drug.
\end{abstract}

Keywords: Garbhshosh, Garbhakshaya, Intrauterine growth restriction, Kshirbasti, Kshirpan

\section{INTRODUCTION}

In Ayurveda text, garbhashosh is also stated as vatabhipanna garbha in term, it can be defined as underdevelopment or under nourishment of part or whole body of the foetus in utero. ${ }^{1}$ Ayurveda is one of the oldest scientific medical systems in the world. The disease named as garbhashosh has been described in classical texts. Ayurveda has its roots deep seated in samhitas especially charakasamhita. This science of longevity has mentioned detailed description of almost all commonly occurring diseases. While describing specific management of garbhashosh, Sushruta suggested use of kshirbasti and medhyanna. ${ }^{2}$

"Garbhashosho cha vatanam kshiram paramucchhate" Ka. Khi. Bhojankalpadhyay. ${ }^{3}$

Acharya kashyapa has described garbhashosh in khilastana, $22^{\text {nd }}$ chapter, while describing vatadosha karma. ${ }^{3}$ Acharya charaka while describing garbhavyapada like nagodar, upavishtak, leengarbha, in sharirstana 
chapter number $8^{\text {th }}$ named as Jatisutriyaadhyaya explained garbhashosh, its etiopathology and treatment. Sushrutacharya while describing garbhadosh and its management entiteled the disease garbhashosh, in the chapter number $10^{\text {th }}$ 'garbhinivyakaran sharir' of sharirstan. ${ }^{1}$ Ashtang Sanghrahakar vridha vagbhata described different aspects of garbhashosh in sharirstan $2^{\text {nd }}$ chapter 'garbhavyapadam sharir'. ${ }^{5}$ Ashtang Hridaya has mentioned the garbhashosh in sharirstan chapter number $1^{\text {st }}$ 'garbhavakrantisharir' while describing etiopathology of garbhavyapada. ${ }^{6}$ In ancient text of ayurveda acharya sushruta in sharirsthan described rupa of garbhashosh as 'matu kukshi na purayati' it means size of abdomen not increases accordingly to the gestational age of mother. Fetus inside uterus remains small for dates. Another important rupa of garbhashosha is 'manda spandana'. ${ }^{1}$

Dalhana in his comentry stated that there is absence of 'oja' in garbha. ${ }^{7}$ Acharya Kashyapa described same symptoms. Acharya Charaka in sharirstsna described a different symptom, of a women having garbhashosha, is she delivers the little one after a year, after attaining proper growth of fetus in utero. ${ }^{8}$ Acharya Vagbhata also opines that the garbha remains for year in the uterus.

Intrauterine growth restriction (IUGR) is defined as babies with birth weight below the tenth percentile for a given gestational age for a given population as a result of pathological restriction in their ability to grow.

\section{Aim}

This study aims at thorough review of published data of kshirbasti with different Ayurveda interventions in the management of IUGR, published from 2010 to 2020 that to explore Ayurveda approach towards IUGR and efficacy of available Ayurveda treatment modalities specifically kshirbasti and kshirpan on the foetal growth and development.

\section{METHODS}

\section{Research question}

In modern medicine treatment of garhashosh (IUGR) is empirically directed towards weight gain of mother and foetus by rest, oxygen $\left(\mathrm{O}_{2}\right)$ therapy, gluco-corticosteroids, nutrition with high protein diet, hydration, mechanical therapy like vibrations, pharmacological therapy- low dose aspirin, hyper alimentation, in the form of trans amniotic, intragastric and intravenous routes. It is very clear from foresaid facts that treatment is cost effective, time consuming and with drastic side effects of drugs and steroids on pregnant mother.

All these facts highlighted that mother suffering form garbhashosh-IUGR, has to face lot of problems. Per se growth retardation in fetus does not cause any harm to mother. Unfortunately for a women with a growth retarded infant, risk of having another is twofold! That's why people of present era are looking forward for Ayurveda treatment modalities. So there is need of strong evidences of safe and effective treatment.

Hence in an attempt to expand the concept of IUGR according to Ayurveda and to yield a flourishing results on IUGR by qualitative analysis of previously published findings of Ayurveda treatment modalities specifically kshirbasti and kshirpan to generate evidence on its safety and efficacy.

\section{Data sources}

The data sources consist of quality literature search.

Electronic databases like PubMed, scopus, DHARA portal, AYUSH Research portal, Ayurveda research data base by MS Baghel, Goggle scholar and manual search in libraries

Records identified through other sources include preferred reporting items for systematic reviews and meta-analyses (PRISMA).

Journals, publications, postgraduate thesis and dissertations.

\section{Criteria of selection}

The relevant research works through different data sources, the result of which were processed, are selected according to the classification criteria.

\section{Year of publication}

Research articles published in 2010-2020.

\section{Language}

Research work published only in English language were included.

\section{Number of citations of the article}

Articles with greater number of citation were given preference.

\section{Study design}

This review included randomized controlled trials (RCTs), controlled clinical trials (CCTs), case reports and case series. Evidence-based studies were given preference and systematic review was done using PRISMA guidelines.

\section{Key words}

Research publications with keywords like kshirbasti, kshirpan, IUGR, garbhshosh, garbhakshay and oligohydramnios were considered for review. 


\section{Types of publications}

Original research articles were taken for study.

\section{DATA COLLECTION}

Details of number of studies identified, screened and assessed for eligibility for inclusion of qualitative synthesis is given in PRISMA flow chart.
The records screened indicates the number of studies that remained after the exclusion of duplicates and studies rejected after reading the abstracts. The number of articles eliminated on the basis of the examination of their reviews.

On the other hand, 6 articles for which the full text is available are assessed in the next step and their final number is given under full-text articles assessed for qualitative and quantitative evaluation of study.

\begin{abstract}
Research work obtained through databases
$(\mathrm{n}=21)$

Searching research work obtained through other sources

$\checkmark$ $(n=4)$

Research work excluded duplicates $(n=9)$

$\sqrt{1}$

Research work assessed for eligibility $(n=16)$

$\sqrt{1}$

Research work excluded with reasons-subject of interest, only abstracts available and others reasons $(n=11)$

$\sqrt{1}$
\end{abstract}

Final full research articles selected for qualitative evaluation of study $(n=6)$

1

Research articles selected for quantitative evaluation of study

$(n=6)$

Figure 1: Selection of research articles for evaluation.

\section{RESULTS}

\begin{tabular}{|c|c|c|c|c|c|}
\hline $\begin{array}{l}\text { Sl. } \\
\text { no. }\end{array}$ & Author & $\begin{array}{l}\text { Journal } \\
\text { YOP }\end{array}$ & $\begin{array}{l}\text { Study } \\
\text { type }\end{array}$ & Methodology & Results \\
\hline 1 & $\begin{array}{l}\text { Dewaik } \\
\text {-ar and } \\
\text { Shinde }\end{array}$ & 2014 & $\begin{array}{l}\text { Control } \\
\text {-led } \\
\text { clinical } \\
\text { trial }\end{array}$ & $\begin{array}{l}\text { Total } 60 \text { patients of garbhashosh (asym } \\
\text { IUGR) having their written consent were } \\
\text { selected and divided into two groups. One } \\
\text { group called trial- } 30 \text { patients, in which } \\
\text { bruhaniya gana sidha kshirbasti and } \\
\text { kshirpan was given, while in another group } \\
\text { called control group- } 30 \text { patients to whom } \\
\text { injection alamine SN and capsule alamine } \\
\text { forte therapy was given. }\end{array}$ & $\begin{array}{l}\text { It is observed that in both trial and } \\
\text { control group, maternal fundal } \\
\text { height, abdominal girth and fetal } \\
\text { abdominal circumference, } \\
\text { amniotic fluid, fetal weight, } \\
\text { ponderal index showed highly } \\
\text { significant improvement } \\
(\mathrm{p}<0.001) \text {. } \\
\text { Upashaya was seen in } 25 \text { patients } \\
(83.33 \%) \text { of trial group and } 21 \\
\text { patient of control group ( } 70 \%) \text {. } \\
\text { Brimhaniya gana sidha kshirabasti } \\
\text { and kshirpana can be given in } \\
\text { IUGR condition to improve the } \\
\text { growth parameters without any } \\
\text { complication. }\end{array}$ \\
\hline 2 & $\begin{array}{l}\text { Kour J } \\
\text { et al }\end{array}$ & 2016 & $\begin{array}{l}\text { A case } \\
\text { study }\end{array}$ & $\begin{array}{l}\text { A } 23 \text { year old primi gravida with } 34 \text { weeks } \\
\text { of gestation USG report showing A.F.I. <4 } \\
\text { shatavari ksheer basti } 500 \mathrm{ml} \text { was } \\
\text { administered through rectal route. }\end{array}$ & $\begin{array}{l}\text { Shatavari kshirabasti is very } \\
\text { effective treatment modality to } \\
\text { increase the amniotic fluid and for } \\
\text { good nourishment of foetus. }\end{array}$ \\
\hline 3 & $\begin{array}{l}\text { Suprab- } \\
\text { ha K et } \\
\text { al }\end{array}$ & 2017 & $\begin{array}{l}\text { A case } \\
\text { series } \\
\text { study }\end{array}$ & $\begin{array}{l}\text { In this case series, total } 3 \text { pregnant patients } \\
\text { completing their } 7 \text { th months of pregnancy, } \\
\text { with the complaint of intrauterine growth }\end{array}$ & $\begin{array}{l}\text { It was observed that after the basti } \\
\text { treatment, there was increase in } \\
\text { the fetal movements, liquor and }\end{array}$ \\
\hline
\end{tabular}




\begin{tabular}{|c|c|c|c|c|c|}
\hline $\begin{array}{l}\text { Sl. } \\
\text { no. }\end{array}$ & Author & $\begin{array}{l}\text { Journal } \\
\text { YOP }\end{array}$ & $\begin{array}{l}\text { Study } \\
\text { type }\end{array}$ & Methodology & Results \\
\hline & & & & $\begin{array}{l}\text { restriction, reduced fetal movement and } \\
\text { oligohydraminos were administered with } \\
\text { shatavaryadi ksheerapaka basti } 450 \mathrm{ml} \\
\text { once daily in the morning, for consecutive } \\
10 \text { days. }\end{array}$ & $\begin{array}{l}\text { also fetal weight. In addition, } \\
\text { there was also increase in } \\
\text { maternal weight and improvement } \\
\text { in fatigue, body ache, etc. From } \\
\text { the study it has been observed } \\
\text { that, in conditions of garbha } \\
\text { kshaya (IUGR), administration of } \\
\text { shatavaryadi ksheerapaka basti is } \\
\text { beneficial in terms of fetal growth } \\
\text { and maternal wellbeing. }\end{array}$ \\
\hline 4 & Singh S & 2017 & $\begin{array}{l}\text { Clinical } \\
\text { trial }\end{array}$ & $\begin{array}{l}\text { Group A consisted of } 30 \text { pregnant subjects } \\
\text { were treated with a combination of } \\
\text { following medicines: dhatri lauha } 250 \mathrm{mg} \\
\text { BD orally with water, yashyimadhu, vidari } \\
\text { siddha ksheerabasti } 60 \mathrm{ml} \text {, calcium } 500 \mathrm{mg} \\
1 \text { OD orally, folic acid } 5 \mathrm{mg} 1 \mathrm{OD} \text { orally. } \\
\text { Group B consisted of } 30 \text { pregnant subjects } \\
\text { were treated with a combination of } \\
\text { following medicines: yashyimadhu, vidari } \\
\text { siddha ksheerabasti } 60 \text { ml, iron supplement } \\
100 \text { mg ferrous ascorbate } 1 \text { OD orally, } \\
\text { calcium } 500 \text { mg } 1 \text { OD orally, and folic } \\
\text { acid } 5 \text { mg } 1 \text { OD orally. Group C consisted } \\
\text { of } 30 \text { pregnant subjects were treated as } \\
\text { control group, they were regularly taking } \\
\text { following medicines since } 4 \text { th month of } \\
\text { pregnancy: iron supplement } 100 \text { mg } \\
\text { ferrous ascorbate } 1 \text { OD orally, calcium } 500 \\
\text { mg } 1 \text { OD orally, folic acid } 5 \text { mg } 1 \text { OD } \\
\text { orally. Evaluation of the efficacy of } \\
\text { treatments was based upon the assessment } \\
\text { of improvements in signs and symptoms. }\end{array}$ & $\begin{array}{l}\text { This analysis shows that, the USG } \\
\text { measurements of fetuses gain in } \\
\text { AC, FL, HC was significantly } \\
\text { more in group A and group B } \\
\text { mothers. } \\
\text { There is significant difference in } \\
\text { baby weight at birth. Group-A and } \\
\text { group-B baby weights at birth } \\
\text { significantly more than group-C. } \\
\text { Amongst the three treatment } \\
\text { modalities, a combination of } \\
\text { yashtimadhu, vidari siddha basti } \\
\text { with dhatrilauha is the best } \\
\text { treatment modality during } \\
\text { pregnancy for maintenance of } \\
\text { good health of both baby and the } \\
\text { mother. }\end{array}$ \\
\hline 5 & $\begin{array}{l}\text { Anu } \\
\text { MS et } \\
\text { al }\end{array}$ & 2018 & $\begin{array}{l}\text { A case } \\
\text { report }\end{array}$ & $\begin{array}{l}\text { A } 28 \text { year old married woman second } \\
\text { gravida with } 33 \text { week of gestation given } \\
\text { her consent admitted for premature uterine } \\
\text { contaction, isoxsuprine hydrochloride } \\
\text { injection } 5 \mathrm{mg} \text { IM } 6 \text { hourly (total } 4 \text { doses), } \\
\text { half tablet of tidilan retard (isoxsuprine } 40 \\
\mathrm{mg}) 1^{\text {st }}, 2^{\text {nd }} \text { and } 3^{\text {rd }} \text { day; betamethasone } 1 \\
\text { ampule IM } 2 \text { doses ( } 12 \text { hours apart) } 4^{\text {th }} \\
\text { day. Shatavaryadi ksheerapaka basti } 450 \\
\text { ml was administered through rectal route } \\
5^{\text {th }} 6^{\text {th }} \text { day shatavaryadi ksheerapaka } 90 \mathrm{ml} \\
\text { orally twice daily empty stomach for a } \\
\text { week. }\end{array}$ & $\begin{array}{l}\text { Shatavaryadi ksheerapaka basti is } \\
\text { found to be very efficient in } \\
\text { preventing premature } \\
\text { contractions. }\end{array}$ \\
\hline 6 & $\begin{array}{l}\text { Jadhav } \\
\text { AS }\end{array}$ & 2017 & $\begin{array}{l}\text { A case } \\
\text { report }\end{array}$ & $\begin{array}{l}\text { A } 23 \text { year old female, primi gravida at } 31 \\
\text { weeks of gestation with moderate } \\
\text { oligohydroamnios; } \\
1^{\text {st }} \text { day=matra basti til taila }-60 \mathrm{ml}, 2^{\text {nd }}-7^{\text {th }} \\
\text { day=ksheerbasti } 100 \mathrm{ml} 7 \text { days, } 8^{\text {th }} \\
\text { day=matra basti til taila }-60 \mathrm{ml}, 9^{\text {th }}-15^{\text {th }} \\
\text { day=ksheerbasti } 100 \mathrm{ml} 7 \text { days, } 16^{\text {th }} \\
\text { day=matra basti til taila }-60 \mathrm{ml} \text { (shatavary, } \\
\text { ashwagandha, phalaghrutasidhha ksheer } \\
\text { basti) }\end{array}$ & $\begin{array}{l}\text { Shatavari, ashwagandha, } \\
\text { phalaghruta sidhha ksheer basti } \\
\text { has proven very effective } \\
\text { modality to increase amniotic } \\
\text { fluid and good nourishment of } \\
\text { fetus in this case. }\end{array}$ \\
\hline
\end{tabular}




\section{DISCUSSION}

In this systematic review, out of these six research works, two research articles explained effectiveness of kshirbasti on IUGR, one research work showed effectiveness of kshirbasti on premature uterine contractions, two research works were carried out to find out effectiveness of kshirbasti on oligohydramnios and one research work was carried out to find efficacy of kshirbasti in IUGR and oligohydramnios as well. Among these six research studies included, four studies mainly on only kshirbasti, two research studies on kshirpan and kshirbasti both. ${ }^{9-14}$

\section{Efficacy of kshirbasti}

The aim of this work to review systematicaly the effectiveness of 'bruhaniya gana siddha kshirbasti and kshirpan' 'shatavari kshirbasti' 'yashtimadhuvidari siddha kshirbasti' 'shatavaryadi ksheerapaka basti' in the patients with IUGR, oligohydramnios, premature uterine contractions showed highly effective results in increasing the maternal weight gain, fundal height, abdominal girth. ${ }^{9,10,12,13}$ Increase in fetal biometry, amniotic fluid index, baby birth weight. Definite need of alternative, safe and effective treatment option through Ayurveda might be quite helpful. Management of premature uterine contractions through shatavaryadi kshirbasti formulation might be useful for further studies in this era.

Bruhaniya gana siddha kshirbasti and kshirpan drugs formulation having dominance of snigdha, sheeta, guru guna, sheeta virya, madhur ras, madhur vipak, pruthvi-aap mahabhutadhikya, vata shaman and anuloman, bhruhaniya, garbhavruddhikar properties. ${ }^{9}$ Combination of kshirpan and kshirbasti given more beneficial results. Treatment modality helped in proper rasadhatu nirmiti, rasaraktadhatu prasadan results in prakrut garbhaposhkansh nirmiti and garbhavridhhi in IUGR.

Drugs in shatavaryadi kshirpak basti endowed with bruhan, balya, pushtidayak, shonitprasadan, vatanuloman properties which help in formation of new tissues and rejuvenating the already formed dhatus. ${ }^{11}$ Shatavaryadi basti consist of shatavari, bala and arjuna, which acting as dhatu vardhak increses the rasa dhatu and in turn increses the amniotic fluid. Dhatu vardhana by constructive metabolism and thus have a definite action on fetel growth related disorders.

Drugs formulation in yashtimadhu, vidari siddha kshirbasti having predominance of madhur rasa, which is indicated in garbhini paricharya. ${ }^{12}$ Ksheer used for basti is much needed during pregnancy as it is having rasayana, vrishya, balya, jivaniya, stanyakara, shramhara properties. Medicated kshir introduced by anal route having more systemic and local effects like great absorptive capacity and vatanuloman. This therapy helped in fulfilling the dietary demands as well as it is preventing the common discomforts observed during pregnancy. In turn helping in normal, healthy, and timely growth of the foetus.
Formulation consist of shatavari, bala, arjuna in shatavaryadi ksheerapaka for basti and ksheerapan preparation drugs posesess antioxytocic, antistress, hypotensive, cardiotonic and vasodilating properties which might be effectively curtailed the progress of premature contractions. ${ }^{13}$ Per rectal basti administration of shatavaryadi kshirpaka for two consecutive days was effective in preventing the uterine contractions and further advancement to preterm labour. Antioxytocic effect of shatavari was proved through many studies as it produce a specific block of pitocin induced contractions, through this research its action as uterine sedative was confirmed.

In shatavari ashwagandha phalaghrita kshirabasti, Shatavari having jivaniya bruhaniya, garbhaprada properties, it also acts as bruhaniya and tarpak for jala mahabhuta which helped in improvement of amniotic fluid. ${ }^{14}$ Ashwagandha posseses bruhaniya, rasayana, deepniya, vrushya and garbhsthapaka properties which acted by providing good nutrition. phalaghruta acts as balya to uterus, its snigdha guna helps in improvement of garbhodak.

\section{Safety of kshirbasti}

According to World Health Organization (WHO) the definition of drug is any substance or product that is used or is intended to modify or explore physiological systems or pathological state for the benefit of recipient. This review yielded and florished lights on safety of kshirbasti treatment modality in treating a disease condition like IUGR, oligohydramnios without any untoward harm to garbhini. Vagbhatacharya had mentioned the characteristics of an ideal drug as a drug, which is having properties of bahukalpa, bahu guna rich in all its characteristics. Through this review study it is been observed that selection of drugs in all kshirbasti formulations were from authentic references, having kapha vataghna, bhruhaniya and garbhavrudhikar properties. Administration was in the correct dose and standard methods of preparation and administration were followed. No severe adverse events were observed in all trials. These case studies focusing to use kshirpak basti, hoping that these drugs will be more effective in counteracting IUGR with its anabolic properties without any side effects. This will be a great contribution to Ayurveda obstetrician in the management of IUGR.

\section{CONCLUSION}

This was a required effort to form the ladder towards basti chikitsa in garbhini, which was not frequently practiced before. Ksheerbasti can be given in a pregnant woman after completion of $28^{\text {th }}$ weeks of gestation. Cost is effective as compared to modern drug and it is safe with no adverse effects. Kshirbasti pratyagam kala was observed in more than 4-6 hours. It can be given in larger quantity i.e. observed is more than $400 \mathrm{ml}$ for effective action and quick absorption through anal route. Kshirbasti as sukhaprasavakara and improving garbhadharan kala and 
liquor increasing effect of basti was observed. Uterine premature contractions can be effectively managed through ksheerbasti.

Funding: No funding sources

Conflict of interest: None declared

Ethical approval: Not required

\section{REFERENCES}

1. Sushruta samhita (Hindi). Motilal Banarasidas, Delhi, 5th Edition. Sharirsthan adhyaya no. 10/62. 1975.

2. Sushruta samhita (Hindi). Motilal Banarasidas, Delhi. 5th Edition, sutrasthan adhyaya no 15/22. 1975.

3. Kashyap samhita Vridhajivaka Vidyotini, Hindi Commentary by Bhaishjyaratnamani DS. Chauckhamba Prakashan, Varanasi. 8th Edition. khilasthan adhyaya no 22 bhojankalpadhyaya. 2002.

4. Charak samhita with Vidyotani Vyakhya (Hindi). Chaukhamba Bharati Academy, Varanasi. 19th Edition. Sharirsthan adhyaya no 8/20. 1993.

5. Ashtang Sangrah Ashtanga Sangrahah with Sarvanga Sundari Vyakhya of Pt. Lalchandra Shastry Vaidya (Hindi). Baidyanath Ayurveda Bhavan Private Ltd. 1st Edition. Sharirstan adhyaya no 2/37. 1989.

6. Ashtang Hruday Ashtanga Hridayam with Sarvanga Sundari Vyakhya (Hindi). Motilal Banarasidas Publishers Pvt. Ltd., Delhi. 1st Edition. Sharirstan adhyaya no 1/43-47. 1990.

7. Dalhantika on Charaka Samhita with Vidyotani Vyakhya (Hindi). Chaukhamba Bharati Academy, Varanasi. 19th Edition, 1993.

8. Charak samhita with Vidyotani Vyakhya (Hindi). Chaukhamba Bharati Academy, Varanasi. 19th Edition. Sharirsthan adhyaya no 2/151993.
9. Dewaikar SJ, Shinde S. Controlled Clinical Evaluation of Bruhaniya Ganasiddha Kshirpan and Kshirbasti in the Management of Garbhashosh with Special Reference to IUGR. J Dent Med Sci. 2014;13(8):30-361.

10. Kour J, Donga SB. Role Of Shatavari Ksheerabasti In The Management Of Oligohydramnios - A Case Study. Int Ayur Med J. 2016;4(10).

11. Suprabha K. Role of Shatavaryadi Ksheerapaka Basti in Garbha Kshaya - Case Series. 2017;2(5).

12. Singh S. Effect of Yashtimadhu, Vidari Siddha Ksheerabasti On Pregnancy. 2017;4(3).

13. Anu MS, Kunjibettu S, Archana S, Dei L. Management of premature contractions with Shatavaryadi Ksheerapaka Basti-A Case Report. 2017;38(3-4):148-52.

14. Jadhav AS. Efficacy of Sharavari and Ashwagandha ksheerbasti in oligohydroamnios: case study. Int J Res Ind Med. 2017;1(4).

15. Deshmukh S, Mundada PS, Ram TS, Gundeti MS. Protocol for Systematic Review and Meta-analysis of Ayurvedic Interventions for Essential Hypertension. J Res Ayur Sci. 2019;3(1):17-21.

16. Liberati A, Altman DG, Tetzlaff J, Mulrow C, Gøtzsche PC, Ioannidis JP, et al. The PRISMA statement for reporting systematic reviews and metaanalyses of studies that evaluate health care interventions: explanation and elaboration. PLoS Med. 2009;21;6(7):1000100.

Cite this article as: Shinde ST. Clinical efficacy of Ayurveda treatment modalities in the management of garbhashosh (IUGR): a systematic review. Int J Adv Med 2020;7:1878-83. 